\title{
The Darkness of God: An Account of Lasting Mystical Consciousness Resulting from an NDE
}

\author{
John Wren-Lewis \\ Department of Religious Studies \\ University of Sydney, Australia
}

\begin{abstract}
This article describes the author's near-death experience (NDE) in 1983 as a result of poisoning. While the experience included few of the features that some researchers have held to be paradigmatic for deep NDEs its consequences were exceptionally profound, inasmuch as a continuing altered state of consciousness has resulted, requiring mystical language to do it justice. Almost every feature of the experience has been antithetical to the author's prior background, both in childhood and in adult life, thereby providing evidence against reductionist explanations of NDE. An account is given of how the new consciousness is affected by various life-circumstances, and of its practical impact on the quality of living.
\end{abstract}

At a time when popularizers are already making claims that NDEs tend to follow an "archtypal" pattern-autoscopic view of the body, journey through a tunnel or valley, emergence into a heavenly landscape or celestial radiance, life-review, encounters with "beings of light," regretful return to the body under instruction from higher powers, etc. - the following account sounds a cautionary note against premature pattern-making. My NDE in Thailand in 1983 had not a single one of these so-called paradigmatic features, yet its consequences seem to have been far more dramatic than any I have yet seen reported in the literature. The experience remains with me not merely as a memory, however vivid, nor merely as a changed attitude to life, however radical; it is still totally present as an almost palpable change of consciousness, a continuous "mystical" state that seems like "eternal life" right now, both waking and sleeping.

On the other hand, my experience also cuts across many of the arguments put forward by skeptics to explain NDEs away as dreamtype experiences derived from birth memories (e.g., Sagan, 1979), childhood fantasies of heaven, or wish-fulfillment (Ehrenwald, 1974). I can speak with some authority about dreams, having been the husband and collaborator of a leading dream psychologist, Dr. Ann Faraday, for nearly two decades (Faraday, 1973 and 1976), and I can state categorically that the NDE was nothing like a dream either in its subjective quality nor, even more important, in its power to pro- 
duce this extraordinary continuing state of consciousness. And to make clear how utterly at odds the experience was with my whole prior background, from birth to middle age, I will start this report with a thumbnail sketch of the life which the NDE itself did not review for me.

As far as birth is concerned, there is of course no way to know for certain how a neonate experiences entry into the world, but on any rational basis the arguments put forward in this journal by Carl Becker against Carl Sagan (Becker, 1982) would certainly apply in my case: I cannot imagine my emergence from the womb in a cold, gloomy English slum in the post-World-War-One depression years felt remotely like the blissful mystical experience I shall be describing here. After that, any religious fantasies in my cramped childhood could only have been of the Jesus-in-white-robes type derived from crude Sunday-school pictures, overshadowed by superstitious fear of a deity so autocratic that he had struck one of our neighbors blind (so my mother believed until her dying day) for uttering the good old English oath "Gorblimey." I rebelled against this superstition into fierce atheism when I encountered the writings of H.G. Wells in my school library, and dedicated myself to science, eventually following Wells's footsteps to Imperial College in the University of London at the start of World War II.

Later, while pursuing a career in industrial research and what is now known as "futurology" (Wren-Lewis, 1975), I came to take a more positive view of Christianity, but remained vehemently humanistic and anti-mystical, playing a leading role in the so-called "Death of God" movement in extreme liberal theology (Robinson, 1963; Wren-Lewis, 1958 and 1964). I dismissed all mysticism as neurotic escape-fantasy (Wren-Lewis, 1966). Even after I left industry in the early 1970s and crossed the Atlantic to teach religious studies and collaborate in my new wife's work with dreams, I remained at a loss to understand how so many educated people could possibly be interested in mysticism. My concern with dreams was from a totally down-to-earth, no-nonsense therapeutic viewpoint; I considered psychedelic drug experiences only mildly interesting, and I dismissed what I read about NDEs as mostly exercises in vivid imagination.

That, briefly, was the John Wren-Lewis who, in his sixtieth year, went for what he was expecting to be a nice quiet family rest in southern Thailand after emerging unscathed from an extended stay in the Malaysian jungle with the famous Senoi "dream-tribe" (Faraday and Wren-Lewis, 1984). When Ann and I, with our teenage 
daughter, boarded a long-distance bus from Surat Thani in the east to Phuket in the west, we knew nothing of articles in the international press about thieves plying travelers with drugged sweets or drinks before making off with their wallets and luggage while they dozed, or of the sensational case where one pathological killer poisoned a whole coachload of people (Neville and Clarke, 1979). We heard one or two rumors, but having experienced nothing but generosity from everyone we'd met in our first month, we discounted them as scaremongering tales spread by hippies who'd eaten too many of the magic mushrooms that are on public sale everywhere in Thai resorts. We had no suspicions whatever of the nice young man who helped us with our luggage and then, on this crowded vehicle in broad daylight, offered us Cadbury's toffees. They tasted distinctly musty, but I sucked on to the (literally) bitter end out of politeness; Ann, less inhibited, spat hers out, and thanks to this I am now alive to tell the tale. For that particular thief evidently went in for injecting his toffees with overdoses, and had we both dozed off we would have slept our way to eternity, while our daughter sat oblivious at the front of the bus, unconcerned, like the other passengers, about her parents taking a "little nap."

When the thief saw Ann wasn't eating her sweet, he realized his plans were foiled and left the bus hastily at the next stop, just as I was beginning to feel drowsy. When my head dropped on my chest and I began to drool, Ann grasped what had happened but thought there was nothing to do now but let me sleep it off, so she stretched me out on the seat with a sleeping bag under my head. After a while, however, as the bus plunged on into the countryside, she noticed with alarm that I was going blue around the lips and had no detectable pulse. With difficulty she persuaded the driver to stop (he thought I was drunk), and after some hassle she and our daughter managed to flag down a van for a ride back to Surat Thani hospital. The doctors were not at all hopeful of saving me, but made the optimistic assumption that my total non-response to pain was due to the drug (they suspected morphine, which is very cheap in Thailand) rather than to imminent death, and plied me with oxygen and antidotes by intravenous drip. It was about seven hours before I showed any evidence of coming round, and they decided to put us all up for the approaching night in a private room.

It was some hours later still before I really surfaced, to find my daughter asking if I wanted supper. For some time after that I was so occupied with getting in touch with where I was and what had been going on that I just didn't think about anything else. Then, after my wife and daughter had gone to sleep, I began to wonder why 
that rather shabby hospital room seemed transcendently beautiful. My first thought was, "Hey, is this why people get hooked on morphine?' but second thoughts told me that after all those hours any drug effects should have worn off (a conclusion since confirmed by leading drug experts I have consulted in Australia). What is more, I had taken part in a lot of research on psychedelic drugs in England in the late 1960s and had some experiences which many less skeptical people would have called religious, including one apparently transcendental vision of white light with LSD (Wren-Lewis, 1971), but the experience in the Surat Thani hospital room was totally different-altogether calmer, without any perceptual distortion, yet at the same time far more impressive. I began to wonder if I'd had some kind of NDE while I was "out," so I tried a technique which Ann and I have sometimes found useful when we wake up knowing we have just had a vivid dream but cannot remember any details.

I lay on the bed, relaxed, and began to take myself back in imagination, by a series of steps, right to the point of coming round: "Here I am, lying on this bed, with my daughter asking if I want supper; here I am, with my eyes still closed, feeling my arm being shaken; here I am, just before that, and . . ' Often this process brings back the dream one has forgotten from just before waking, but what came back this time was nothing like a dreammemory. What came flooding back was an experience which in some extraordinary way was still with me, indeed had been with me ever since I came round, without focusing on it until now. It was as if I had come out of the deepest darkness I had ever known, which was somehow still there right behind my eyes.

One of the near-death experiences reported to Kenneth Ring (Ring, 1982) was from a woman who said she had been enveloped in "a very peaceful blackness . . . a soft, velvet blackness,' and I now know exactly why she went on to say that her later happiness, which astonished her friends in the hospital, was not just her reaction to being alive, but was "connected with that total peaceful blackness." But I feel the need to say something even stronger to do justice to my experience. A phrase which has since come to mind is one I read in an ancient alchemical text quoted by Carl Jung (Jung, 1966) as evidence that alchemy was concerned with psychological or spiritual changes rather than chemical ones: the text states that at one point in the transformation, the operator "falls into the black sun" "and experiences "a palpable absence of light" (an interesting psychological anticipation of black holes?). The darkness I experienced was somehow radiant, and I find myself wanting to use the paradoxical expression "deep but dazzling darkness" which the 
mystical poet Henry Vaughan applied to God (Vaughan, 1958).

I am not trying to draw any particular theological or metaphysical conclusions when I use the word "God" here. On the contrary, my readings in theology and metaphysics in earlier years never conjured up to my mind anything remotely like my experience. I am simply saying that since the experience, Vaughan's line and a whole host of other statements made by mystics in all religions seem to make sense as word-straining attempts to describe the extraordinary state in which I found myself-for instance, the Hebrew poet's cry in Psalm 139 that "the night shineth as the day," or Mohammed's statement that he experienced "the Night of Power" (Bucke, 1923), or the assertion of St. John of the Cross that he encountered God as "a dark cloud illuminating the night" (John, 1958). I am even led to wonder if similar experiences rather than mere metaphysical speculation, underlay the references to "cosmic darkness" in some of the world's primordial creation stories, such as the "darkness on the face of the deep" in Genesis or the "darkness at first by darkness hidden"' in the Rig Veda (Radhakrishnan and Moore, 1945). Could the Hebrew creation story have been inspired by the experience of Abraham when he went into a deep sleep at sunset "and lo, a dread and a great darkness fell upon him"' (Genesis 15:12)?

Most NDE literature emphasizes experiences of light rather than of darkness; if dark is mentioned at all, it is usually in connection with a dark tunnel or valley through which the person seems to hurtle towards a bright light or heavenly landscape beyond. One man interviewed by Raymond Moody, however, suggested something altogether more positive in the experience of darkness when he said it was "so deep and impenetrable that I could see absolutely nothing, but this was the most wonderful, worry-free experience you can imagine" (Moody, 1975). I too felt utterly secure in my darkness, knowing that all life's struggles were over and I had "come home", to a state beyond all danger, where I no longer needed or wanted anything because everything I could possibly want or need was already mine. That shining darkness seemed to contain everything that ever was or could be, all space and all time, and yet it contained nothing at all, because the very word "thing" implies separate entities, whereas what I experienced was an utterly simple being-ness without any kind of separation-the very essence of aliveness prior to any individual living beings. Another paradoxical expression, this time from Eastern mysticism, seems the only one that is remotely adequate- "the living Void" of Taoism (Lao-Tzu, 1972), Hinduism (Griffith, 1982), Tibetan Buddhism (Blofeld, 1970), and Zen (Watts, 1957). In Christian mysticism this same idea is found in Meister 
Eckhart's description of the Godhead as "empty, as though it were not" (Eckhart, 1981) and in Jacob Boehme's reference to God as "a suprasensual abyss" (Boehme, 1970).

I join hands here with another of Moody's NDE subjects (Moody, 1975) who reported "just floating and tumbling through space" and then added, "I was so taken up with this void that I just didn't think of anything else." The idea that a void could be interesting would have seemed like nonsense to me before, but it now makes total sense. In fact the state I am trying to describe seems to defy all ordinary canons of logic, and my deepest resonance is to Buddha's classic description of Nirvana (Pali Canon, 1968), which simply piles one paradox upon another:

Monks, there exists that condition wherein is neither earth nor water nor fire nor air; wherein is neither the sphere of infinite space nor of infinite consciousness nor of nothingness nor of neither-consciousness-norunconsciousness; where there is neither this world nor a world beyond nor both together nor moon-and-sun. Thence, monks, I declare there is no coming to birth; thither is no going; therein is no duration; thence is no falling; there is no arising. It is not something fixed, it moves not on. That indeed is the end of ill.

And even "the end of ill" has to be contradicted too if I am to do justice to my experience, for it was in no way merely negative. It was a "worry-free experience," ' 'a very peaceful blackness,"' but there was nothing passive or lifeless about it-it was "the peace of God that passeth understanding." Words like "bliss" or "joy" are equally inadequate, for they are far too limited, which I think must be why one of the oldest religious documents known to mankind, the Katha Upanishad, says that when its young hero Nachiketa went to the kingdom of death, he discovered a new kind of self, the Universal Self, Brahman, who is "effulgent Being, joy beyond joy" (Hume, 1974).

I have no recollection whatever of any transition from ordinary consciousness to this nirvanic condition. I can't positively deny having any sensation of leaving my body or passing through a tunnel-I just don't remember anything at all after feeling drowsy on the bus. In the shining darkness there was no feeling of having gone anywhere-it was more like finding that everywhere had become present to me. Yet there was a sense of having ceased to be the ordinary me, which is my subjective reason for believing that my experience was, like Nachekita's, a trip into the kingdom of death rather than, say, some kind of hyping-up of the brain resulting from the drug. My feeling is, quite precisely, of having gone beyond death, though I don't mean of surviving death, because the Self which I 
had become was so much more than my ordinary self that I had no recollection of, almost no interest in, my personal history. Yet at the same time it would be misleading to say that I lost my past or the people I have known in ordinary life; although there was nothing like the life-review which forms a prominent part of many NDEs, I still had a sense that my whole life as John Wren-Lewis was completely present, and could have been reviewed if I'd wanted, just as I could have met my deceased relatives or "angels, archangels and the whole company of heaven" if I'd been inclined. But in that shining dark, I simply felt no need for any separate experience.

Words and logic come under even greater strain when I attempt to describe how John Wren-Lewis with his personal history came back from the nirvanic state. The very phrase "came back" is wrong, for two reasons. First, as I said earlier, the nirvanic state didn't become just a memory; when I eventually "clicked back into it" by using the dream-recall exercise, I found it was still right there with me, even though not in quite the same way as when I was (from the doctor's point of view) unconscious. And secondly, it makes no sense in terms of ordinary logic to talk about coming or moving out of a state in which time had ceased to exist. This last is a problem with which all the great religious systems of the world have wrestled in their various doctrines of creation. If God is everything, how can anything else exist? and if God is eternal, "when" can time possibly "come" into being? I used to think these were abstract metaphysical issues and probably meaningless word-juggling; I feel sure now that those doctrines were attempts to express just the kind of impossible transition I went through from nirvana to the rebirth of John.

So I can only say that it seemed as if the impossible happened, and a movement took place in eternity which is beyond all movement. In the Jewish Kabbalah, it is said that the en sof, the Limitless, created (or creates, for this happens beyond time) a space within itself so that limited being can also exist (Schaya, 1973). In the Taittiriya Upanishad (Hume, 1974) it is said that Brahmin changed (or changes) from the pure Unmanifest to the Manifest (though of course there is nothing other than Brahmin for Brahmin to manifest to!). In the creation-story of the Maoris of New Zealand it is said that "in the beginning there was Te Kore, the Nothing . . . and into the void of nothingness and night came a gleam of light, a speck of light. Light unseen, for there was none to see" (Yearbury, 1976). To coin my own phrase, it was as if the personal "I" budded out from that eternity of shining dark, without my ceasing to be the shining darkwhich I suppose is what Hindu theology is trying to express by the 
statement that Atman, the individual self, is identical with Brahman, the universal Self.

And the whole process was blissful, which is another marked contrast between my experience and a great many NDEs. There was no sense of regret at coming back from the heavenly state or "place" into the narrow world of physical existence. Manifestation seemed to be just another mode, as it were, of the bliss of the Unmanifest, the Dark. I resonate to those wonderful words attributed to God in The Book of Job: "Where was thou when I laid the foundations of the earth . . . when the morning stars sang together, and all the sons of God shouted for joy?' I feel I know exactly why the Bible says that God looked upon the creation and saw that it was good. But before my experience, the idea of God creating the world always conjured up images of a kind of super-builder at work, whereas the "feel" of my experience was nothing like that. It was more like Aristotle's idea of created things being drawn into existence by the sheer radiance of divine beauty; the bud that was me opened out, as it were, in response to that black sun which was also, in some utterly paradoxical sense, my-Self. I was alpha and omega, the beginning and the end of the creation-process. Could there have been an experience like this, I wonder, behind A. N. Whitehead's strange theory that the universe exists in the response of the final nature of God to the primordial nature of God (Whitehead, 1969).

I have put all this in the past tense, a description of something that happened in Thailand, but that leaves out the most astonishing thing about it, namely that it is all still here, both the shining dark void and the experience of myself coming into being out of, yet somehow in response to, that radiant darkness. My whole consciousness of myself and everything else has changed in an almost tangible way; in the early days, I kept putting my hand to the back of my head to make sure the skull was still there, feeling for all the world as if the doctors had removed it and exposed my brain to the infinite darkness of space. It is no longer the sixty-year-old John who looks at the environment, but the shining dark void which is in some strange sense also "I" - and what I perceive with my eyes and other senses is a whole world, my body and mind included, that seems to be coming fresh-minted into existence moment by moment, each instant evoking the utter delight of "Behold, it is very good!' To resort yet again to paradox, I seem to be simultaneously at a vast distance from everything and yet inside everything. When I perceive, say, a chair or a tree, I seem to see it through the wrong end of a telescope, yet I also have the constant sense of being the chair or tree perceiving itself. I was quite taken aback, recently, 
when I read the statement of Meister Eckhart that "The eye with which I see God is the eye with which God sees me" (Eckhart, 1981).

I must reiterate here my earlier observation that this is quite different from the expanded consciousness given by psychedelic drugs, though it is every bit as palpable. It is in no sense a "high"-on the contrary, its feeling-tone is one of gentle equanimity. In fact I think it is almost misleading to call it an altered state of consciousness, for my feeling, after living with it for nearly two years, is that in some strange way it is not really extraordinary at all. It is like having come home to something I have always known deep down, which I suppose must be what Plotinus meant when he said (Gould, 1963) that the Ultimate Oneness is not "other"-it is we in our so-called normal state of consciousness who are "other," estranged from the true ordinariness of reality. And of course, the most striking difference between this consciousness and psychedelic experience is precisely that it is still with me, undiminished, after all this time, and shows no signs of fading (cf. Masters and Houston, 1967).

I hasten to add that I do not enjoy this consciousness all the time, though I wish I could-but there is no sense of "coming down" as with psychedelics. What happens is something I would have found utterly incredible had I heard of it second-hand. I simply forget about this pearl of great price, and drift off into all kinds of preoccupations, mostly trivial, thereby reverting to my old way of experiencing myself and the world. At first, in Thailand, I again and again caught myself thinking, "Oh, God, it's gone"-but then, as soon as I focused on the fact that I was missing something from life, it all came flooding back, with no effort on my part at all, the shining dark void at the back of my head and behind everything else, and the experience of everything coming freshly into glorious new existence now! and now! and now! I think this must be what is meant by the mystical notion that so-called normal human life is really a state of chronic forgetfulness of "who we really are," or by the statement of Plotinus (Gould, 1963) that the Supreme is always with us but we do not always look at it, or by the Christian doctrine that it is we who turn away from God, not God from us. I suppose my NDE must have somehow shocked me into recognizing the Supreme, so that my forgetfulness of "who I really am" is now spasmodic rather than chronic.

Needless to say, it took me some time-several weeks-to come to terms with all this, and only as time went by did I realize that, in keeping with its sense of being more ordinary than ordinary, the new consciousness neither brought nor demanded any drastic changes 
of lifestyle or personality. I was still recognizably John Wren-Lewis, I did not lose my taste for meat or wine or humor, and I found no urge or need to spend long periods in meditation. I have for some years enjoyed half-hour spells of meditation without finding the process any big thing, and while I certainly enjoy meditation more with the new consciousness, this is no different from my increased delight in other experiences: I don't find that meditation, diet or any other kind of discipline has any effect either on the frequency with which I drift out of the mystical consciousness, nor on my ability to click back into it. I now understand what the modern mystic Da Free John means when he states in his autobiography, "There is only the ordinary" (Jones, 1972), an idea clarified in one of his tapes by the statement that after his final experience of God-realization, he went home with his wife and watched TV. As the old Chinese saying has it, before enlightenment, hew wood and draw water; after enlightenment, hew wood and draw water.

What the new consciousness has brought about is a subtle but radical change in attitude to life as a whole, which corresponds so closely with the traditional definitions of enlightenment that I use the word without apology. In the first place, I no longer have any fear of dying. This is a well-known result of NDEs, and often goes hand-in-hand, paradoxically, with greater enjoyment of living, but for me it would be quite false to attribute my change of attitude to a metaphysical conviction that "death is not the end," or that there is a "world beyond." My changed feeling about death is simply part and parcel of a much more general, all-embracing experience for which the most apt term is the Buddhist notion of non-attachment. It is the practical counterpart of the paradox I have mentioned already, that nirvanic consciousness is totally complete in itself and yet still takes delight in manifesting. I find I no longer have any urgent desire for good things in the way I used to have (I suppose Buddhists would call it "craving") because the shining dark is in itself all the happiness I could possibly want, yet that does not in the least diminish my enjoyment of good things when they come-in fact I enjoy them more than ever. And as the ultimate instance of this principle, I enjoy living without concern about dying, for the fulness of "eternal life' ' is now! and now!, not in whatever the future may hold, either in the body or (perhaps) in some new manifestation elsewhere. On the other side of this coin, I still get pleasure, indeed more pleasure than ever before, from "good" experiences like sunsets or birdsong or great art or pleasant people or delicious food, yet I can (sometimes at least) get as much pleasure from things which in my old state of consciousness I would have called nondescript, like the 
Surat Thani hospital room, or even downright nasty, like a filthy wet day or a heavy cold. This last discovery, that I could possibly enjoy a cold - not merely wallow in the indulgence of a day in bed, but actually get a kick from the sensations in my nose and throatwas probably the biggest of the many surprises that this new consciousness has brought me. For although I knew from the first that my fear of death was a thing of the past, I had no such assurance about pain; in fact I speculated, right from the very first night, that the marked contrast between my joy in "coming back" and the feelings of regret reported in so many NDEs might be due to the fact that my close encounter with death came from a pain-killing drug, whereas most people have to return to very painful bodies. And over the next few weeks I found that headaches and travel sickness did indeed distract me from the new consciousness quite powerfully, so that I had to wait until they had passed for it to take possession of me again.

Then, just as I had resigned myself to the idea that my "enlightenment" must be of a very inferior kind, since it apparently gave me none of the immunity to suffering which is supposed to characterize the enlightened person in Eastern thought, I began to notice changes. The feeling of being "open to the Void" at the back of my head seemed to have spread, without my noticing it happening, down my spine to the middle of my back. And around the same time, I found that the tinatus (hissing in the ears) from which I've suffered for some years had changed from being an annoyance which I could at best forget at times, and at worst could drive me nearly crazy, to a positively delightful sound which I welcomed as an old friend whenever it forced itself on my attention. I also found myself actually enjoying tiredness and the many minor pains that beset a sixtyyear-old body, a startling verification of Freud's contention (Freud, 1977; Marcuse, 1955) that pleasure and pain are often a matter of how we perceive precisely the same sensation. Then came my first post-NDE cold, which proved a startling revelation of hitherto unsuspected potentiality for enjoyment, and around that time I found the feeling of openness had spread still further down my back, right into my buttocks - a kind of upside-down version of the Hindu kundalini which is supposed to flow up the spine (Krishna, 1971; Sanella, 1976.)

So although my entry into Nirvana hasn't transformed me into Instant Saint or Hero-I still get annoyed when I think someone is trying to push me around, and I still keep aspirin in the house in case I get pain I can't enjoy-it does seem to have plunged me into an adventure of consciousness wherein I have no idea what the next 
surprise is going to be. It would be dizzy-making if it weren't so fascinating, and I often feel as if I have been literally born again into a new life, where I'm still very much an infant finding my way around. I find my old life now seems like a distant memory-not actually forgotten or blurred, but somehow cut off, so that recalling it requires the same kind of effort as remembering lines of a play I once knew by heart but haven't performed for years. This kind of feeling is apparently quite a common result of NDEs, according to a recent survey in Vital Signs (1984).

On the other hand, my new life often seems to be a fultillment of the old in ways I'd never before dreamed of. In particular, this adventure of consciousness gives me a research project for such years as remain to me far more challenging and exciting than anything that ever came my way in my earlier career as a scientist; all my interest in dreams and altered states of consciousness since I left industry (Wren-Lewis, 1974) seems like just a preparation for the work I now have to do in exploring this new state, such as a study of its effect on my dream life (Wren-Lewis, 1985). I find myself sharing with both modern NDEers and mystics of all ages an immense sense of gratitude for this gift which life has bestowed on me, and this is perhaps the most important of all the paradoxes I have now come to understand-that the mystical sense of the utter goodness of the universe as it is in no way lessens the desire to contribute to the wortd. On the contrary, that desire is an integral part of the mystical consciousness, an overflowing of thanks for the sheer joy of being. In the words of William Blake (Blake, 1948), "Gratitude is heaven itself," and the other name for gratitude is love.

\section{REFERENCES}

Becker, C. The failure of saganomics: why birth models cannot explain near-death phenomena. Anabiosis, 1982, 2, 102-109.

Blake, W. The Portable Blake (A. Kazin, Ed.). New York: Viking, 1971.

Blofeld, J. The Way of Power: A Practical Guide to the Tantric Mysticism of Tibet. London: Allen \& Unwin, 1970.

Boehme, J. Six Theosophic Points and Other Writings. Ann Arbor, MI: University of Michigan Press, 1970.

Bucke, R. M. Cosmic Consciousness. New York: Dutton, 1923. Eckhart, Meister. Meister Eckhart: The Essential Sermons, Commentaries, Treatises and Defence (F. Colledge and B. McGinn, Trans.). Ramsey, NJ: Paulist Press/Classics of Western Spirituality, 1981.

Ehrenwald, J. Out-of-the-body experiences and the denial of death. 
Journal of Nervous and Mental Disease. 1974, 159, 227-233. Faraday, A. Dream Power. New York: Berkley, 1973.

Faraday, A. The Dream Game. New York: Harper \& Row/Perennial Library, 1976.

Faraday, A., and Wren-Lewis, J. The selling of the Senoi. Lucidity Letter. 1984, (1), 1-2.

Freud, S. Sigmund Freud on Sexuality (A. Richards, Ed.). Harmondsworth, England: Penguin, 1977.

Gould, T. Platonic Love. London: Routledge \& Kegan Paul, 1963. Griffith, B. The Marriage of East and West. London: Collins, 1982. Hume, R. E. (Trans.) The Thirteen Principal Upanishads. London: Oxford University Press, 1974.

John of the Cross, Saint. The Ascent of Mount Carmel (E. A. Peers, Trans.). New York: Doubleday/Image, 1958.

Jones, F. (Da Free John). The Knee of Listening. Clear Lake, CA: Dawn Horse Press, 1972.

Jung, C. G. Psychology and Alchemy: Vol. 12 of Collected Works. Princeton: The University Press/Bollingen Series, 1966.

Krishna, G. Kundalini: The Evolutionary Energy in Man. Berkeley, CA: Shambala, 1971.

Lao Tzu. Tao Te Ching (G. -F. Feng and T. English, Trans.). New York: Vintage Books, 1972.

Marcuse, H. Eros and Civilization. Boston: Beacon, 1955.

Masters, R., and Houston, J. The Varieties of Psychedelic Experience. New York: Dell/Delta, 1967.

Moody, R. Life After Life Covington, GA: Mockingbird, 1975. Neville, R., and Clarke, J. The Life and Crimes of Charles Sobraj. London: Cape, 1979.

Pali Canon. Minor Anthologies of the Pali Canon (F. L. Woodward, Trans.). London: Oxford University Press, 1968.

Radhakrishnan, S., and Moore. C. A. A Source Book of Indian Philosophy. Princeton, NJ: The University Press, 1945.

Ring, K. Frequency and stages of near-death experience. In C. R. Lundahl (Ed.), A Collection of Near-Death Research Readings. Chicago: Nelson-Hall, 1982.

Robinson, J. A. T. Honest to God. London: S. C. M. Press, 1963. Sagan, C. Broca's Brain. New York: Random House, 1979.

Schaya, L. The Universal Meaning of the Kabbalah. Baltimore, MD: Penguin, 1973.

Sanella, L. Kundalini-Psychosis or Transcendence? San Francisco: Dakin, 1976.

Vaughan, H. The Night. In L. C. Martin (Ed.), Collected Works, 1958. 
Vital Signs, 1984, 4 (3).

Watts, A. The Way of Zen. New York: Vintage Books, 1957. Whitehead, A. N. Process and Reality. New York: MacMillan/Free Press, 1969.

Wren-Lewis, J. Integrity in apologetics: or, the dangers of resorting to bluff in theology. In D. Paton (Ed.) Essays in Anglican Self-Criticism. London: S. C. M. Press, 1958.

Wren-Lewis, J. Does science destroy belief? In C. F. O. Moule (Ed.), Faith, Fact and Fantasy. London: Collins/Fontana, 1964.

Wren-Lewis, J. Love's coming-of-age. In C. Rycroft (Ed.), Psychoanalysis Observed. Baltimore, MD: Penguin, 1966.

Wren-Lewis, J. What Shall We Tell the Children? London: Constable, 1971.

Wren-Lewis, J. Resistance to the study of the paranormal. Journal of Humanistic Psychology. 1974, 14.

Wren-Lewis, J. Teaching scientists to think about the future. In A. Toffler (Ed.), Learning for Tomorrow. New York: Random House, 1975.

Wren-Lewis, J. Dream lucidity and the near-death experience: a personal report. Lucidity Letter, 1985, 4 (2).

Yearbury, P. K. The Children of Rangi and Papa: The Maori Story of Creation. Christchurch, New Zealand: Whitcoull, 1976.

Requests for reprints to:

John Wren-Lewis

c/o P.O. Box 445

Lane Cove, NSW 2066

Australia 